\title{
GLOBAL WARMING AND RICE BASED CROPPING SYSTEM
}

\author{
Ms. Aarati Nepal, MSc. Soil SC. ${ }^{9}$
}

\begin{abstract}
International Pannel for Climate Change approximates that the global temperature would rise between $1.5^{\circ}$ and $4.5^{\circ}$ Celsius by some time in twenty-first century. Since the advent of the industrial revolution in the 1700s, human beings have devised many inventions that burn fossil fuels. Burning these fossil fuels as well as other activities such as clearing land for agriculture or urban settlements, releases some of the gases that trap heat in the atmosphere leading to global warming. Carbon dioxide, methane Nitrous oxide chloro-fluoro-carbons comprises the green house gases. Soil in the earth surface is viewed both as source and sink for most of the green house gases. Agricultural practices such as rice cultivation and clearing of the biomass results in the emission of green house gases. It is always not too late for good beginning, so knowledge and research is emphasized for understanding the green house gases emission and its reduction from agricultural practices.
\end{abstract}

\section{Introduction}

There is continuous flow of radiation from the sun in the universe to the earth. In long run energy absorbed from the sun must be balanced by out-going radiation from the earth and the atmosphere. Radioactive atmospheric gases in the earth's atmosphere absorb and remit the part of outgoing energy and radiation from the earth to outer atmosphere. This layer of gases in combination with water vapour acts like a glass of a greenhouse admitting sunshine but preventing heat from the escaping. This effect is called Green House Effect and the gases which can absorb the heat radiation from the earth are therefore called Green House Gases. It is now highly probable that certain green house gases causes global warming of the atmosphere and this warming will have profound and adverse consequences for millions of people in the world.

\section{Green House Gases and their Sources}

Carbon dioxide $\left(\mathrm{CO}_{2}\right)$, methane $\left(\mathrm{CH}_{4}\right)$, Nitrous oxide $\left(\mathrm{N}_{2} \mathrm{O}\right)$, Chloro-fluoro-carbons (CFCs) comprise the major green house gases. Carbon dioxide constantly circulates in the environment through a variety of natural processes know as carbon cycle. Carbon dioxide is released to the atmosphere when solid waste, fossil fuels (oil, natural gas, and coal), and wood and wood products are burned. Man cuts down huge tracts of trees for timber or to clear land for agricultural farming, industries or increasing human habitations. This deforestation reduces number of trees available to absorb carbon dioxide. The largest source of methane in the atmosphere is natural wetlands, rice paddies and livestock. Biomass burning, natural gas production, termites landfills and coal mining also release methane.

Nitrous oxide is released by oceans and soils but human activities such as biomass burning and the use of fertilizers play a role that is not yet fully understood or quantified. Chloro-fluorocarbons is purely due to sophisticated life style of human being. chloro-fluoro-carbons and nitrous oxides are many times more potent than the same quantity of carbondioxide or methane. Green house gases are formed by natural processes also but Chloro-fluoro-carbons is purely man made. The additional that human activities put into the atmosphere during

\footnotetext{
${ }^{9}$ Soil Scientist, Soil Management Directorate, Department of Agriculture, Harihar Bhawan. Email: aarati_nep@rediffmail.com
} 
1980s came principally from fossil fuels. Additions from changes in land use, such as deforestation, are estimated to have been one-fifth to one-half as large.

To maintain the global energy balances, both the atmosphere and the earth surface will warm until the outgoing energy equals the incoming energy. It has become difficult to meet this balance because of increasing demand for fossil fuel and increasing pressure on land and other natural resources. The destruction of forest biomass for cultivation and loss of vegetation are implicated for their effects on carbon sequestration and carbon dioxide emissions to the atmosphere. These changes may also promote nitrate leaching to groundwater and emissions of nitric oxide and nitrous oxide to the atmosphere. However, the effects of changes in land use on carbon and nitrogen dynamics in soil are complex and not well understood. Soil -the major sink for carbon if disturbed, accelerates the global warming. Agricultural practices such as, rice based cropping system is considered as the major GHG emitter. Rice cultivation will continue to increase at or beyond its current rate to meet the rice supply of growing populations. This paper presents an overview of GHG emission from rice based cropping system. Furthermore, it emphasize on the various processes during rice cultivation contributing for gases emission and its possible mitigation options.

\section{Objective}

This paper relies on the knowledge gained during masters research on rice and secondary information collected from various literatures. The main objective of this paper's to review the process of global warming as contributed by rice based cropping system.

\section{Rice based cropping system and global warming}

Rice (Oryza sativa) is the second largest crop in planting acreage after wheat in the global context. It is a staple food crop for more than a billion people in South and East Asia. Most of the world's population growth is in the rice growing countries. Paddy rice corresponds to approximately $10 \%$ of the global cultivated agricultural area, constitutes approximately $20 \%$ to the global natural freshwater wetland area (Timsina and Cornnor, 2001). Paddy fields are one of the dominant anthropogenic sources of methane to the atmosphere (estimated as 15\% of global methane emission (IPCC, 1994). Methane is an extremely heat trapping gas - one molecule of methane is 20 times more efficient at trapping infrared radiation from the earth's surface than a molecule of carbon dioxide.

\section{Rice Plant as an Emitter of Methane}

Rice cultivation encompasses the unique practices of flooding the soil unlike other crops. The rice fields are flooded with available irrigation water upto $4-6 \mathrm{~cm}$ depth. Being a semi aquatic plant and it also contributes in methane production like other aquatic plant (Wassmann et al., 1993). Isumu et al. (1990) measured the methane emission rate much higher than the calculated methane emission rate that would result from transpiration from rice. The main passageway of methane emission from anaerobic paddy soils to the atmosphere is through the arenchyma of the rice plant. Rice roots could absorb methane gas in the gas phase without water uptake. They suggested that methane dissolved in the soil water surrounding the roots diffuses into the cell-wall water of the root cells, gasifies in the root cortex, and then is mostly released through the micropores in the leaf sheaths.

\section{Micro Organisms Involved in Methane Production}

Microorganisms serve as an essential role in the ecosystem by recycling the carbon and mineral elements for reconversion into biomass. The energy stored in organic matter is released in oxidative reactions, in which oxygen serves as the ultimate electron acceptor. 
When the food chain is disrupted due to localized exhaustion of the oxygen supply or to toxicity towards the microorganisms, the carbon -oxygen cycle is placed at risk. Microbial communities are a vulnerable part of ecosystem and any condition -that threatens them is very dangerous for the whole cycle (Pradhan and Pradhan, 2006).

Due to flooding of soil in rice cultivation anaerobic condition is created in the root surface of the plant and consequently to the inhabiting microorganisms in the rhizosphere and nearby. In such condition anaerobic methanogenic bacteria produce methane as a product of their energy metabolism. The process is termed as methanogenesis. In well aerated land, aerobic methnotropic bacteria oxidize methane as an energy source with methanol as product. Hence methane production from well aerated land is much lower than from flooded land (Brady and Weil, 2002).

\section{Nitrogen-gases from Rice Field}

Among the nitrogen-gases, nitrous oxide $\left(\mathrm{N}_{2} \mathrm{O}\right)$ is a powerful greenhouse gas, about 310 times more effective at trapping heat than carbon dioxide on a molecular basis. This dangerous gas emission from rice field is mainly attributed to the heavy use of nitrogenous fertilizers. Formation and emission of $\mathrm{N}_{2} \mathrm{O}$ takes place wherever nitrogen occurs and is therefore more or less a function of the nitrogen turnover in agriculture. However, $\mathrm{N}_{2} \mathrm{O}$ emissions from paddy fields are considered to be very low. The importance of ammonia volatilization as a $\mathrm{N}$ loss mechanism from paddy fields has also been established in recent studies, though its environmental significance is not yet known. (De Datta and Buresh 1989).

\section{Rice Straw Burning}

There is a common practice of burning the crop residues such as straw. Burning of these materials converts a great deal of nitrogen and sulfur, and some phosphorus to gaseous form and they are lost from the site. It emits large quantities of carbon monoxide, $\mathrm{CO}_{2}$, fine particulate matter, and volatile hydrocarbons into the air, and somewhat lesser amounts of oxides of nitrogen and oxides of sulfur (Brady and Weil, 2002). These gases in the atmosphere enhance the atmospheric gases. There is common fallacy among the farmers that burning of straw in field adds nutrients than by incorporating. These residues if returned back to the soil, have immense potential for providing plant nutrient as well as adding organic matter to soil. Various scientists reported the increase in rice yield with the incorporation of straw in the rice field. They recommend incorporating the residues few weeks ahead of transplanting rice.

\section{Decomposition of Incorporated Residues}

Microbial decomposition proceeds most rapidly in the presence of plentiful supplies of oxygen. Oxygen supplies may deplete when soil pores are filled with water preventing the diffusion of $\mathrm{O}_{2}$ to and from the atmosphere. The product of decomposition in such condition includes wide variety of organic compounds including methane gas. Anaerobic decomposition releases relatively little energy for the organisms involved therefore the end product still contains much energy. For example bio-gas and slurry from bio-gas chamber where anaerobic decomposition operates. The $\mathrm{CH}_{4}$ is the major product of anaerobic decomposition form the biogas chamber which is used for burning. Similarly, the bio gas slurry also contains the nutrients required by plant (BSP-Nepal-2007).

Hence in the rice field, due to flooding residue incorporated undergoes anaerobic decomposition. The methane production from residue incorporated paddy field is higher than unincorporated (Chidthaisong et al., 1996). In well aerated condition the final product is mostly $\mathrm{CO}_{2}$ instead of methane. Methane has higher potential for global warming than $\mathrm{CO}_{2}$. 
The Carbon:Nitrogen $(\mathrm{C}: \mathrm{N})$ ratio of the residues being incorporated also influence the quantity of gas to be produced. The rice or wheat straw with high $\mathrm{C}: \mathrm{N}$ ratio are difficult to decompose and involves large number of microorganisms for longer period. In anerobic condition, the higher activity of mehtanogenic bacteria could produce higher methane than from low $\mathrm{C}: \mathrm{N}$ ratio residues. Microorganisms in rice field are found to be responsible for:

\section{Conclusion and Recommendation}

Rice based agriculture plays a very important role in the global inventory of methane gas. Worldwide, irrigated rice cultivation is considered to be among the highest sources of atmospheric methane and to some extent nitrous oxide under certain water management regimes. Since rice is the staple food, neither its crop yield could be sacrificed nor could its pattern be changed to avoid green house gases emission. On the other hand, rise in earth's temperature enforces the soil to behave as sink for green house gases rather than source. The understanding of microbial processes and turnover of carbon and nitrogen in soil opens the possibility for reduction of green house gases emission. Some of the strategies to reduce green house gases emission from agricultural system are to practice Integrated Plant Nutrient System (IPNS) that includes use of nutrient enriched organic fertilizers. Soils can be modified and improved by the application of fertilizers designed to compensate for specific mineral deficiencies, inadequate soil drainage can be improved by tile drains, ditches. Cropping system based on nutrient supplying power of soil and low soil nutrient requiring crop in the marginal land should be selected as carbon sink. In the agricultural country like Nepal, agricultural practices could be the major source of green house gases emission. The nation should think of reducing these gases with available technology and take an opportunity of selling these emission reduction units as per the Article 6.1 of the Kyoto Protocol.

\section{REFERENCES}

1. Brady, N. C. and R. R. Weil. 2002: The nature and properties of soils. (13 ${ }^{\text {th }}$ ed.) Pearson Education. 960p.

2. BSP-N, 2007: Bio-slurry promotio -Nepal. Training on trainers on improved use of bioslurry. Bhakhundole, Lalitpur.

3. Chidthaisong A., K. Inubushi, Y. Muramatsu and I. Watanabe. 1996: Production potential and emission of methane in flooded rice soil microcosms after continuous application of straws. Microbes and Environments 11: 73-78

4. De Datta, S.K. and R.J. Buresh, 1989: Integrated nitrogen management in irrigated rice. Adv. Soil Sci., 10: 143-169.

5. IPCC 1994 and Climate change 1994: Cambridge University Press, Cambridge, UK

6. Isumu N., S. Mariko and K. Aoki.1990. Mechanism of Methane Transport from the Rhizosphere to the Atmosphere through Rice Plants. Plant Physiology. 94:59

7. Pradhan, P. and B. Pradhan. 2006: Environment and natural resources: Concepts, methods, planning and management. Quest Publication. Kathmandu, Nepal. 402p

8. Timsina, J., and Connor, D. J. 2001: Productivity and management of rice-wheat cropping systems: issues and challenges. Field Crops Res. 69, 93-132.

9. Wassmann, R., H. Papen, H. Rennenberg. 1996: Methane emission from rice paddies and possible mitigation strategies. Pergamon-Elsevier Science Ltd, Germany

10. Nouchi, I., S. Mariko and K. Aoki. 1990: Mechanism of Methane Transport from the Rhizosphere to the Atmosphere through Rice Plants. Plant Physiology 94:59-66. 